\title{
The Effect of Management Capabilities in Implementing Good Corporate Governance: A Study from Indonesia Banking Sector
}

\author{
Sotarduga NAPITUPULU ${ }^{1}$, Ina PRIMIANA ${ }^{2}$, Sulaeman R. NIDAR ${ }^{3}$, Nury EFFENDY ${ }^{4}$, Devy Mawarnie PUSPITASARI ${ }^{5}$ \\ Received: August 07, 2019 Revised: November 01, 2019 Accepted: November 15, 2019
}

\begin{abstract}
The study attempts to examine the effect of the capabilities of banking companies, namely the dynamic and unique capabilities, on the implementation of GCG in Indonesia. The effect of organization capabilities on the implementation of GCG is essential since both of them can demonstrate the quality of the company's ability to compete and innovate. This study will also examine the influence of moderating variables, namely the fit and proper test. The methodology used in this study is the structural equation methods and using primary data with board of directors of commercial bank in Indonesia. The test results suggest the positive direct effect of unique capabilities on GCG. The findings show that the capabilities of the top management, both unique and dynamic capabilities, influence the implementation of GCG. Then, the variable of fit and proper test can also strengthen the relationship between them. Both unique capabilities and fit and proper test have a strong and positive impact on GCG. Meanwhile, dynamic capabilities have a negative impact on GCG even though it's not significant and contradictive with earlier studies. In the context of the banking industry growth and sustainability, this matter is important to examine. Top management behavior in operating their organization is important to be investigated.
\end{abstract}

Keywords : Unique Capabilities, Dynamic Capabilities, Fit and Proper, Corporate Governance, Indonesia

JEL Classification Code : G30, G34, G38

\section{Introduction}

According to the survey conducted by the Asian Corporate Governance Association in September 2016, the companies in Indonesia occupy the most recent position in

1 First Author and Corresponding Author, Doctoral Student, Department of Management, Faculty of Economic and Business, Padjadjaran University, Indonesia. [Postal Address: Jl. Raya Bandung Sumedang KM.21, Hegarmanah, Kec. Jatinangor, Kabupaten Sumedang, Jawa Barat 45363, Indonesia] Email: sotarnapit@gmail.com

2 Associate Professor, Department of Economic and Business, Padjadjaran University, Indonesia.

3 Associate Professor, Department of Economic and Business, Padjadjaran University, Indonesia.

4 Associate Professor, Department of Economic and Business, Padjadjaran University, Indonesia.

5 Doctoral Student, Department of Management, Faculty of Economic and Business, Padjadjaran University, Indonesia.

(c) Copyright: Korean Distribution Science Association (KODISA)

This is an Open Access article distributed under the terms of the Creative Commons Attribution Non-Commercial License (http://Creativecommons.org/licenses/by-nc/4.0/) which permits unrestricted noncommercial use, distribution, and reproduction in any medium, provided the original work is properly cited. the implementation of good corporate governance (GCG). In the survey results, it is mentioned that Indonesia has made some improvements in the GCG regulations of the company, yet the enforcement is still weak. The improvement of some of the regulations is not matched by the progress in implementing them. The financial crisis in 2008 triggered by the activity in the banking industry has made the issue of bank governance even more a concern. Mulbert (2009) stated that the formulation of banking governance is different from other corporate governance regulations since most of the banking regulations and deposits are within the framework of the principal agent. Banking governance must also be based on a financial system stability perspective, which then can be said that banking governance is notable both in its regulation and enforcement because it is related to the stability of a country's financial system as a whole. Hopt (2013) emphasized that GCG is crucial for financial institutions because the failure of corporate banking governance can result in a financial crisis.

Many factors can affect good corporate governance. The organizational structure has an indirect influence through the 
determinant of resources on GCG (Pertusa-Ortega et al., 2010). Stahl (2007) stated that leadership is the key to the successful GCG practices of companies. Clark et al. (2004) argued that business environment influences the implementation of GCG by increasing the contribution of corporate strategy formulation.

Another factor is the company's capability. Company capabilities can be divided into unique and dynamic capabilities. The dynamic business conditions with rapid technological change require the companies to have dynamic capabilities. Meanwhile, the existence of intense competition between companies encourages them to have unique capabilities, which can relatively strengthen the position of a company in the industry. Teece and Pisano (2003) examined the dynamic capabilities which have an influence on the implementation of GCG. Then, in a study on the pharmaceutical industry in India, Rentala et al. (2014) stated that there is the impact of unique capabilities on the quality of GCG implementation. Many existing studies on the financial institution, corporate governance rely on traditional performance measures such as Tobin's Q, return on equity (ROE), and return on assets (ROA) (Salim et al, 2016). The use of these traditional performance measures, however, has been criticized in the context of corporate governance studies.

The future challenges in the banking industry are related to the implementation of the ASEAN Economic Community (AEC) in the banking industry which will be put into effect starting in 2020. With the introduction of the AEC, all goods and services including banking products and services are free to penetrate the entire ASEAN countries. Thus, the national banking sector must be able to improve its competitive position through the right business strategy. A good bank with GCG has potential to encourage innovation and growth, especially for emerging and developing economies like Indonesia (Diallo, 2017).

This study attempts to examine the effect of the capabilities of banking companies, namely the dynamic and unique capabilities, on the implementation of GCG in Indonesia. The effect of human resource capabilities on the implementation of GCG is essential since both of them can demonstrate the quality of the company's ability to compete and innovate. This study will also examine the influence of moderating variables, namely the fit and proper test.

\section{Literature Review}

GCG has several definitions. According to the OECD (2004), GCG is a structure in which shareholders, directors, and managers set company goals, prepare the way to achieve goals, and evaluate the performance of achieving those goals. According to the Iskander and Chamlou (2000), GCG can be defined as an organization and regulation that can influence the expectations of control in the management of a company's resources. In Indonesia, according to the Financial Services Authority (OJK), GCG is a procedure for the corporate management (banking) that applies the principles of openness, accountability, responsibility, independence, and fairness. As a complement to understand more about GCG, there's an absolute requirement to achieve GCG, which is a board of directors that fulfill its statuary duty to oversee the management of the company, to guard the interests of shareholders and to ensure conformity with regulatory requirements (Salim et al., 2016).

Implementation of GCG in a company is crucial and is expected to reduce the agency costs and the emergence of information asymmetry due to the separation of ownership and management control over a company (Djokic \& Duh, 2016). GCG implementation can be an effective monitoring of company management activities. In addition, the implementation of GCG can encourage optimization of the use of available resources, leading to an increase in the company performance. In banking, Beck et al. (2003) stated that banks really require GCG implementation because of their unique business characteristics compared to other companies or financial institutions. Information asymmetry is something that arises from businesses on charges, which is a fundamental aspect that has the potential to cause problems. The application of GCG is notable for banks to reduce the potential problems (Furfine, 2001).

The application of GCG in banks in Indonesia has been regulated by the Financial Services Authority (OJK) through the Financial Services Authority Regulation No. 55/POJK.03/2016 on the Implementation of Governance for Commercial Banks to regulate the implementation of GCG that applies to the Conventional Commercial Banks in Indonesia. The main points of GCG implementation are realized in the implementation of the duties and responsibilities of the Board of Commissioners and Directors; the completeness and implementation of the duties of the committees and work units that carry out the bank's internal control function; the implementation of the compliance, internal auditor, and external auditor functions; the application of risk management, which includes internal control systems; the provision of funds to the related parties and the provision of large funds; the bank strategic plan; and the transparency of financial and non-financial conditions. The purpose of GCG implementation according to the OJK is to improve bank performance, to protect the interests of stakeholders, and to improve the compliance with the applicable laws and regulations as well as the ethical values that are generally accepted in the banking industry. Therefore, it is necessary to implement good corporate governance and improving the quality of good corporate governance implementation is an effort to strengthen the internal condition of the national banking.

The application of GCG in banks in Indonesia has five principles, namely:

1) Transparency, which is the openness in presenting the material and relevant information and the openness in the decision-making process.

2) Accountability, namely the clarity of functions and implementation of accountability of the Bank's organs so 
that the management becomes effective.

3) Responsibility, which is the suitability of the Bank's management with the applicable laws and regulations as well as the principles of sound Bank management.

4) Independence, which is the Bank's management in a professional manner without any influence or pressure from other party.

5) Fairness, namely justice and equality in fulfilling the rights of stakeholders that arise based on the agreements and legislation.

\subsection{Unique Capabilities}

Unique capabilities can be defined as the specific resources owned by a company to be able to increase the productivity of resources within the company (Makadok, 2001). Unique capability is a characteristic of a company relative to other companies, which is a strength of the company to be able to excel in the competition in the industry. Unique capabilities related to core capabilities that are the expertise of the company in relation to the customers or buyers of the company's products (Wheelen et al., 2015). Unique capability is one of the determinants of the quality of GCG implementation in the company. Boasson and MacPherson (2001) examined the pharmaceutical industry in the US, concluded that unique capabilities have an important role in the quality of corporate GCG implementation. Elements in the unique capabilities of the study are the characteristics and location of the company. Rentala et al. (2014) also examined this on the pharmaceutical industry in India, deduced that unique capabilities influence the quality of GCG implementation.

Therefore, according to the authors, the unique capabilities possessed by a bank, which is a specific and a superior ability compared to other banks, can be a determinant in the implementation of good corporate governance. These capabilities can then improve the management's ability to optimize the company resources to produce products that are superior in the market and can win the market competition. Table 1 shows the dimensions of unique capabilities based on several studies.

Table 1: Unique Capability Dimensions

\begin{tabular}{|c|l|c|l|}
\hline & \multicolumn{1}{|c|}{ Authors } & Year & \multicolumn{1}{c|}{ Dimensions } \\
\hline 1 & Wheelen et al. & 2015 & $\begin{array}{l}\text { Tangible assets; Intangible assets; } \\
\text { Organizational capabilities; } \\
\text { HR assets; Competence }\end{array}$ \\
\hline 2 & $\begin{array}{l}\text { Robinson and } \\
\text { Pearce }\end{array}$ & 2015 & $\begin{array}{l}\text { Tangible assets; Intangible assets; } \\
\text { Organizational capabilities; } \\
\text { HR assets; Competence }\end{array}$ \\
\hline 3 & $\begin{array}{l}\text { Boasson and } \\
\text { MacPherson }\end{array}$ & 2001 & $\begin{array}{l}\text { Characteristics; Innovation; } \\
\text { Company location }\end{array}$ \\
\hline
\end{tabular}

In this study, the unique capability dimensions used are the company characteristics and innovation. Company characteristics variable constructed by three indicators as stated in questionnaires. The first indicator of company characteristics is whether the structure of bank organization is complete and meet the bank's necessity, there are no double position and no family relation to the organization. Second indicator is whether the bank has all facilities to support their employees. The third indicator of company characteristics is whether the bank has planned and evaluation system that involving every element in their organization. Meanwhile, innovation variable as a dimension of unique capabilities has four indicators. The first one is whether bank advantages in products more than the other bank's product. High quality employee to produce high quality bank product and a good system of budgeting are the second and third indicators of innovation. The last indicators of innovation is the continuity of the bank to innovate to keep their high level of product quality.

\subsection{Dynamic Capabilities}

Dynamic capability is the company's ability to adapt to the changes in the environment. According to Teece et al. (1997), dynamic capability is the ability of a company to transform its characteristics and how the company adapts and reintegrates its internal and external resources in the organization to remain competitive in the conditions of the dynamic environment. A research on dynamic capabilities as the determination of the application of GCG has been conducted by Teece and Pisano (2003) who stated that dynamic capabilities affect the implementation of corporate GCG. In the banking sector, as the global competition and the community living standards increase, banks are forced to have better product differentiation and services that meet the needs of the community which can add value. This capability is the dynamic capability, which is a determinant of the implementation of GCG in the company (Mavridis \& Kyrmizoglou, 2005). Table 2 shows the dimensions of dynamic capabilities, according to several studies.

Table 2: Dynamic Capability Dimensions

\begin{tabular}{|c|l|c|l|}
\hline & \multicolumn{1}{|c|}{ Authors } & Year & \multicolumn{1}{|c|}{ Dimensions } \\
\hline 1 & $\begin{array}{l}\text { Pavlou and EI } \\
\text { Sawy }\end{array}$ & 2011 & $\begin{array}{l}\text { Sensitivity capability; Learning } \\
\text { capability; Integration capability; } \\
\text { Coordination capability }\end{array}$ \\
\hline 2 & Lin and Huang & 2012 & $\begin{array}{l}\text { Marketing capability; Change } \\
\text { management capabilities; } \\
\text { Innovation capability; Integration } \\
\text { capability }\end{array}$ \\
\hline 3 & Mauludin et al. & 2013 & $\begin{array}{l}\text { Discovering capability; Capability to } \\
\text { protect resources; configuration } \\
\text { capabilities }\end{array}$ \\
\hline
\end{tabular}

Dynamic capabilities used in this study are the sensitivity and innovation. Sensitivity constructed by three indicators. The first one is whether the bank has employee performance measurement based on corporate values, targets, and reward and punishment system. The second indicator is that bank facilitates ideas by giving rewards. Last indicator for sensitivity is that bank hearing opinions from every perspective during the decision making process. A second instrument for dynamic capabilities is innovation, which consist of four indicators. The first indicator of innovation in dynamic capabilities is whether the bank has a team to 
facilitate creativity, and those creativity can be used to increase bank's performance in term of service production. Those products of service by the creative team can increase bank performance in term of competition and problem solving, and at last, bank gives rewards for their employee who initiate those innovations.

\subsection{Fit and Proper}

Another factor affecting the quality of GCG implementation is the process of due diligence in occupying the position of bank leader. Khalid and Nadeem (2004) suggested that both in the developing and developed countries, the quality of GCG implementation is determined by the assessment in the fit and proper test of bank leaders. Hopt (2013) stated that GCG practices in banks are different from other industries, and the existence of fit and proper tests has an effect on the quality of GCG implementation. One component which drives the effective GCG implementation is a process that ensures that bank leaders lead and run the GCG process correctly through the fit and proper tests.

The fit and proper test is a moderating variable in this study. The quality of GCG implementation can be encouraged by having a good fit and proper test process. Indirectly, the fit and proper test has an effect on the implementation of GCG through the ability of the leadership of the bank management when running their positions after going through the fit and proper test.

\section{Research Methods and Materials}

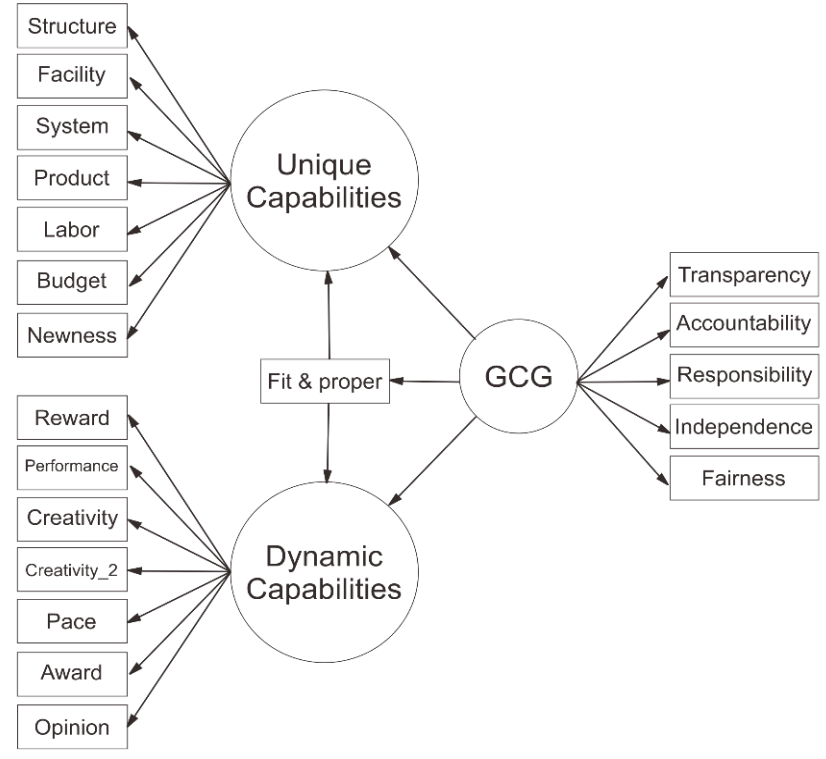

Figure 1: SEM Framework

This study is a quantitative study, in which the hypothesis testing was done through the empirical data testing. The hypothesis was based on the literature review explained in the previous section. The analytical method used was the Structural Equation Model (SEM).

Figure 1 depicts SEM framework used in this study. Circles in Figure 1 containing latent variable, namely unique capabilities and dynamic capabilities. Unique capabilities affected by company characteristics (structure, facility, system) and innovation (product, labor, budget, newness). Dynamic capabilities affected by sensitivity (pace, award, opinion) and innovation (reward, performance, creativity, creativity_2). GCG constructed by five indicators, which are transparency, accountability, responsibility, independence, and fairness. As a structural path GCG affected by all two latent variables used in this framework, unique and dynamic capabilities.

This study analyzed using the primary data obtained from questionnaires directly distributed to the respondents. The object of the study was all national commercial banks operating in Indonesia. The respondent in this study was one person from the board of directors at the bank, in which the total respondents were 115 respondents. There are 4 hypotheses tested. $\mathrm{H} 1$ is that the unique capabilities affect the quality of the GCG implementation in commercial banks in Indonesia. $\mathrm{H} 2$ is about fit and proper test that can moderate the unique capability, variable which strengthens GCG implementation. Then for $\mathrm{H} 3$ is that dynamic capabilities affect the quality of the GCG implementation in commercial banks in Indonesia. Last, H4 is about fit and proper test that can moderate the dynamic capability variable which strengthens GCG implementation.

\section{Results and Discussion}

The SEM analysis in this paper was conducted using STATA software. The model was going through several model fit tests, namely Chi-squared test, comparative fit index (CFI), and Tucker-Lewis index (TLI). Model fit tests are necessary to understand how our model predicts the sample variance-covariance matrix. STATA provided model fit indices test and our model indicating a good fit since CFI and TLI value close to 1 . The CFI of our model is 0.826 and the TLI is 0.802. Chi-squared test showing p-value of 0.000 means that we reject the null hypothesis that our SEM model fit no worse that the saturated model (SM), and conclude that our SEM model fits worse than the SM.

The results of the whole model test meet the reliability and validity test rules of both the overall model and partial variables. The test results based on the table above tells the positive direct effect of unique capabilities and fit and proper test on GCG. The estimated direct effect from the unique capabilities to GCG is 0.82 and statistically significant at 1 percent alpha. Fit proper test showing the same direction as unique capabilities, its direct effect to GCG is 0.19. In addition to showing direct effect, the coefficient of fit and proper test also indicate the moderate effect, which highly statistically significant. Meanwhile, 
there's a negative direct impact of dynamic capabilities on GCG even though it's practically small and not statistically significant. The total effect of unique capabilities and dynamic capabilities on GCG can be calculated by adding direct effect of latent variables on GCG and indirect effect of latent variables on moderation variable (fit and proper test) on GCG. The total effect of unique capabilities to GCG therefore can be calculated as $0.82+(0.67 \times 0.19)$, meaning the total effect is 0.95 . Then for the dynamic capabilities the total effect on GCG is 0,10 , from $-0.08+$ $(-0.13 \times 0.19)$.

Table 3: SEM Estimation ( $\left.{ }^{*} p<0.01\right)$

\begin{tabular}{|c|c|c|c|c|c|}
\hline Variables & Coeff. & Std. Error & Error Var. & Raykov's rel. & Remarks \\
\hline 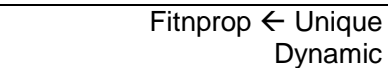 & $\begin{array}{l}0.67^{*} \\
-0.13\end{array}$ & $\begin{array}{l}0.17 \\
0.18\end{array}$ & $\begin{array}{l}0.55 \\
0.98\end{array}$ & \multirow[b]{2}{*}{0.90} & \multirow[b]{2}{*}{$\begin{array}{l}\text { No problem with } \\
\text { discriminant \& convergent } \\
\text { validity }\end{array}$} \\
\hline $\begin{array}{r}\text { GCG } \leftarrow \text { Fitnprop } \\
\text { Unique } \\
\text { Dynamic }\end{array}$ & $\begin{array}{l}0.19^{*} \\
0.82^{*} \\
-0.08\end{array}$ & $\begin{array}{l}0.07 \\
0.14 \\
0.14\end{array}$ & $\begin{array}{l}0.68 \\
0.33 \\
0.99\end{array}$ & & \\
\hline \multicolumn{6}{|c|}{ Measurement } \\
\hline Facility & $0.77^{*}$ & 0.04 & 0.41 & \multirow{6}{*}{0.94} & \multirow{6}{*}{$\begin{array}{l}\text { Problem with discriminant } \\
\text { validity, No problem with } \\
\text { convergent validity }\end{array}$} \\
\hline System & $0.79^{*}$ & 0.04 & 0.37 & & \\
\hline Product & $0.79^{*}$ & 0.03 & 0.36 & & \\
\hline Labor & $0.81^{*}$ & 0.03 & 0.35 & & \\
\hline Budget & $0.88^{*}$ & 0.02 & 0.22 & & \\
\hline Newness & $0.87^{*}$ & 0.02 & 0.24 & & \\
\hline Creativity_2 & $0.92^{*}$ & 0.02 & 0.15 & \multirow[t]{4}{*}{0.92} & \multirow{4}{*}{$\begin{array}{l}\text { Problem with discriminant } \\
\text { validity, No problem with } \\
\text { convergent validity }\end{array}$} \\
\hline Pace & $0.62^{*}$ & 0.06 & 0.61 & & \\
\hline Award & $0.63^{*}$ & 0.06 & 0.60 & & \\
\hline Opinion & $0.57^{*}$ & 0.06 & 0.67 & & \\
\hline \multicolumn{6}{|l|}{ GCG: } \\
\hline Transparency & $0.67^{*}$ & 0.05 & 0.55 & \multirow{5}{*}{0.85} & \multirow{5}{*}{$\begin{array}{l}\text { No problem with } \\
\text { discriminant \& convergent } \\
\text { validity }\end{array}$} \\
\hline Accountability & $0.70^{*}$ & 0.05 & 0.50 & & \\
\hline Responsibility & $0.84^{*}$ & 0.03 & 0.29 & & \\
\hline Independence & $0.56^{*}$ & 0.07 & 0.69 & & \\
\hline Fairness & $0.90^{*}$ & 0.03 & 0.19 & & \\
\hline
\end{tabular}

The coefficient for unique capabilities, dynamic capabilities, and fit and proper test can be interpreted as the correlation between those variables on GCG. Squaring those coefficients indicating how much the variance in an indicator is explained by the latent variable. The squared standardized factor loading of 0.82 is -0.08 indicating that 82 percent of the variance in unique capabilities is explained by GCG, and for dynamic capabilities the squared factor is minus 8 percent, then for fit and proper test is 19 percent. Both 'unique' and 'dynamic capabilities' standardized loadings are above threshold of 0.4, lending support to the model (Mehmetoglu \& Jakobsen, 2016). Error variance on the Table 1 shows the opposite of squared factor loadings, which shows the amount of variance in the indicator that not explained by the latent variable. Error variance of unique capabilities is 0.33 or 33 percent, showing that 33 percent of the variance is not explained by GCG. Dynamic capabilities' error variance is 99 percent. Those high numbers of error variance oh dynamic capabilities tell that most of its variance could not be explained by GCG and by knowing the insignificant and small number of coefficients of dynamic capabilities we know that dynamic capabilities is not too relatable with GCG. Raykov's reliability is also conducted to know the factor/scale reliability, which means the proportion of the total variation in a scale formed by the indicators that is attributed to the true score (Raykov, 1997; Acock, 2013). As seen in Table 1, all variables have high Raykov's factor reliability coefficient, more than the consensus of 0.7 as it notably the minimum level of reliability for SEM model.

The results of unique capabilities are consistent with several previous studies, including the unique relationship between capabilities and GCG reinforced by Makki and Lodhi (2014) which explained that there is an important structural relationship between corporate governance, intellectual capital efficiency, and financial performance. This study concludes that corporate governance does not improve financial performance directly. On the contrary, the governor of the company can increase it significantly through the utilization of intellectual capital resources. This study provides the empirical evidence that a company with good corporate governance measures increases IC efficiency, 
which ultimately results more in return on investment, return on equity, and net income. The study explains that the application of corporate governance can increase HR assets (intellectual capital) and company performance. This occurs because the era of tangible assets has ended as well as the accumulation of financial capital and the addition of production land has been abandoned. Challenges and the new era of intellectual capital, human capital, and nontangible assets have replaced the old era. Thus, organizations need to reengineer the process of the management of intellectual capital, encourage innovation capacity, build new patterns, and pay attention to the intangible assets of knowledge. It is also crucial to maintain its members and collaborative networks as well as to build organizational relationships (Kasmawati, 2017).

The results of dynamic capabilities are in opposite with several previous studies, including the relationship between dynamic capabilities and GCG reinforced by Mulyana and Sutapa (2016), which depicted that the innovation capabilities significantly influence performance. The performance improvement of creative industry players can be done by building good collaborative networks and developing innovation capabilities (packaging, products, markets, and processes) that are in accordance with the consumer needs. The performance of creative industries can be improved through collaborative networks that encourage the creation of competitive advantage. Likewise, optimal performance can be achieved if the creative industry has a competitive advantage by innovating something new and different from the competitors. Building a good collaborative network is required to encourage the innovation growth and to create the competitive advantage. The innovation development and the creation of competitive advantage are done by building appropriate collaborative networks.

\section{Conclusions}

This study shows that the variables of capabilities strengthen the quality of GCG practices, both for the unique and dynamic capabilities. The fit and proper test variable is proven to strengthen the influence of the variables of capabilities on the quality of GCG practices. This study is useful for observers and researchers, and they can develop this study by using different methodologies, variables, data, or proxies. This study is useful for researching the behavior of banks, financial service authorities, or banking practitioners to monitor GCG. The banking sector is important in economics because it can trigger a crisis once the governance of the bank becomes chaotic. Also, the banking sector is one of the promising industries in the world. A better-developed banking sector can enhance the economic growth.

\section{References}

Asian Corporate Governance Association. (2016). CG WATCH 2016: Ecosystems matter. Asia's path to better home-grown governance. Special Report.

Acock, A. C. (2013). Discovering structural equation modeling using Stata. Stata Press Books. https://ideas.repec.org/b/tsj/spbook/dsemus.html.

Boasson, V., \& MacPherson, A. (2001). The role of geographic location in the financial and innovation performance of publicly traded pharmaceutical companies: Empirical evidence from the United States. Environment and Planning A, 33(8), 1431-1444. https://doi.org/10.1068/a3431.

Beck, T., Demirguc-Kunt, A., \& Levine, R. (2003). Bank supervision and corporate finance National Bureau of Economic Research. Working Paper No. w9620. http://www.nber.org/papers/w9620

Clark, G., Palaskas, T., Tracey, P., \& Tsampra, M. (2004). Globalization and competitive strategy in Europe's vulnerable regions: Firm, industry and country effects in labor-intensive industries. Regional Studies, 38(9), 10851100. https://doi.org/10.1080/0034340042000292656.

Diallo, B. (2017). Corporate governance, bank concentration and economic growth. Emerging Markets Review, 32, 28-37. https://doi.org/10.1016/j.ememar.2017.05.003.

Djokic, D., \& Duh, M. (2016). Corporate governance quality in selected transition countries. Managing Global Transitions, 14(4), 335-350.

Financial Services Authority. (2016). Financial Services Authority Regulations No. 55/Pojk.03/2016 on Implementation of Governance for Commercial Banks. Jakarta, Indonesia.

Furfine, C. H. (2001). Banks as monitors of other banks: Evidence from the overnight federal funds market. The Journal of Business, 74(1), 33-57. http://www.jstor.org/stable/10.1086/209662

Hopt, K. J. (2013). Corporate governance of banks and other financial institutions after the financial crisis. Journal of Corporate Law Studies, 13(2), 219-253. https://doi.org/10.5235/14735970.13.2.219.

Iskander, M., \& Chamlou, N. (2000). Corporate governance: A framework for implementation. The World Bank. https://doi.org/10.1596/0-8213-4741-1.

Kasmawati, Y. (2017). Human Capital dan Kinerja Karyawan (Suatu Tinjauan Teoritis). Journal of Applied Business and Economic, 3(4), 265-280. https://journal.lppmunindra.ac.id/index.php/JABE/article /download/1781/1393.

Khalid, A. M., \& Nadeem, H. (2004). Corporate Governance of Banks in Pakistan: A Profile. Centre for Management and Economic Research, Lahore University of Management Sciences, Lahore, India.

Lin, K. W., \& Huang, K. P. (2012). Dynamic capability and its effects on firm performance. American Journal of Applied Sciences, 9(1), 107-110.

Mehmetoglu, M., \& Jakobsen, T. G. (2016). Applied 
statistics using Stata: a guide for the social sciences. London: Sage.

Makadok, R. (2001). Toward a synthesis of the resourcebased and dynamic-capability views of rent creation. Strategic Management Journal, 22(5), 387-401. https://doi.org/10.1002/smj.158.

Makki, M. A. M., \& Lodhi, S. A. (2014). Impact of corporate governance on intellectual capital efficiency and financial performance. Pakistan Journal of Commerce and Social Sciences, 8(2), 305-330. http://hdl.handle.net/10419/188140.

Mauludin, H., Alhabsji, T., Idrus, S., \& Arifin, Z. (2013). Market orientation, learning organization and dynamic capability as antecedents of value creation. Learning Organization and Dynamic Capability as Antecedents of Value Creation, 38-48. https://papers.ssrn.com/sol3/papers.cfm?abstract_id=231 8141.

Mulyana, \& Sutapa. (2016). Dampak collaborative networks pada peningkatan kinerja industri kreatif. Prosiding Seminar Nasional Multi Disiplin Ilmu \& Call For Papers Unisbank (SENDI_U) Ke-2 Tahun 2016, 778-785. https://www.unisbank.ac.id/ojs/index.php/sendi_u/article /view/4267.

Mavridis, D. G., \& Kyrmizoglou, P. (2005). Intellectual capital performance drivers in the Greek banking sector. Management Research News, 28(5), 43-62. https://doi.org/10.1108/01409170510629032.

Mulbert, P. O. (2009). Corporate governance of banks. European Business Organization Law Review, 10(3), 411-436. https://doi.org/10.1017/S156675290900411X.

OECD. (2004). The OECD principles of corporate governance. Contaduríay Administración, (216). http://dx.doi.org/10.22201/fca.24488410e.2005.562.

Pavlou, P. A., \& El Sawy, O. A. (2011). Understanding the elusive black box of dynamic capabilities. Decision Sciences, 42(1), 239-273. https://doi.org/10.1111/j.15405915.2010.00287.x.

Pertusa-Ortega, E. M., Molina-Azorín, J. F., \& ClaverCortés, E. (2010). Competitive strategy, structure and firm performance: A comparison of the resource-based view and the contingency approach. Management Decision, 48(8), 1282-1303. https://doi.org/10.1108/00251741011076799.

Raykov, T. (1997). Scale reliability, Cronbach's coefficient alpha, and violations of essential tau-equivalence with fixed congeneric components. Multivariate Behavioral Research, 32(4), 329-353. https://doi.org/10.1207/s15327906mbr3204_2.

Rentala, S., Anand, B., \& Shaban, M. (2014). Technological capabilities and firm resources as determinants of export competitiveness: Evidence from Indian pharmaceutical industry using quantile regression approach. Journal of Medical Marketing, 14(2-3), 133-144. https://doi.org/10.1177/1745790414564262.

Robinson, R., \& Pearce, J. (2015). Strategic management. New York: McGraw-Hill Education.

Salim, R., Arjomandi, A., \& Seufert, J. H. (2016). Does corporate governance affect Australian banks' performance?. Journal of International Financial Markets, Institutions and Money, 43, 113-125. https://doi.org/10.1016/j.intfin.2016.04.006.

Stahl, J. (2007). The influential leader. Leader to Leader, 2007(46), 49-54. http://onlinelibrary.wiley.com/doi/10.1002/lt1.257/full.

Teece, D. J., Pisano, G., \& Shuen, A. (1997). Dynamic capabilities and strategic management. Strategic Management Journal, 18(7), 509-533. https://doi.org/10.1002/(SICI)10970266(199708)18:7<509::AID-SMJ882>3.0.CO;2-Z.

Teece, D., \& Pisano, G. (2003). The dynamic capabilities of firms. In Handbook on knowledge management (pp. 195213). Berlin, Heidelberg: Springer. https://link.springer.com/chapter/10.1007/978-3-54024748-7_10.

Wheelen, T. L., Hunger, J. D., Hoffman, A. N., \& Bamford, C. E. (2015). Concepts in strategic management and business policy: Globalization, innovation, and sustainability. Essex, UK: Pearson Education Limited. 